\title{
Biological studies on the filefish Setphanolepis diaspros, Fraser-Brunner, 1940 (Monacanthidae) from the Gulf of Suez, Egpyt.
}

\author{
Azza A. El-Ganainy and Manal M. Sabrah \\ National Institute of Oceanography and Fisheries (NIOF), B.O. Box 182, Suez, Egypt. \\ E. mail: manal_sabrah@yahoo.co.uk
}

\section{ABSTRACT}

The reproductive characteristics and stomach contents of the filefish Stephanolepis diaspros were investigated in the Gulf of Suez during the period from 2004 to 2007 . The overall sex ratio of males to females was estimated as 1.00: 0.18 , where females were represented in small sizes $(8.0-16.0 \mathrm{~cm})$, while males largely outnumber females up to the length interval of $16.0-26.0 \mathrm{~cm}$. The monthly average values of gonad weight percentages and monthly different maturity stages showed that the species spawns during summer with intensive spawning in May. The length at first sexual maturity was estimated at $9.5 \mathrm{~cm}$ for males and $8.5 \mathrm{~cm}$ for females. The diet of file fish consisted of a wide variety of items, dominated by crustaceans and mollusks. Algae, echinoderms, coelenterates and fish remains were also demonstrated in the stomachs. Sponges, hydrozoans, foraminifera and Bryozoa were also preyed by the file fish. The maximum feeding intensity was attained in spring, while the minimum was observed during summer (June to September).

Key words: Stephanolepis diaspros, sex ratio, reproductive biology, feeding habits.

\section{INTRODUCTION}

Representatives of the family Monacanthidae (file fishes) are widely distributed in shelf waters of the tropical and subtropical Indian and Pacific oceans (Assadi and Dehghani, 1997). S. diaspros is known from the Western Indian Ocean: the Persian Gulf to the Red Sea (Hutchins, 1984) and as a lessepsian migrant, in the Mediterranean Sea (Randall, 1995). It inhabits coastal rocky substrate, usually with vegetation (Golani et al., 2002). It lives in small groups and feeds on small invertebrates plucked from rocks. They are important component of fisheries in many countries (Nakazono and Kawase, 1993; Mancera-Rodriguez and Castro-Hernández, 2004). In the Gulf of Suez, Stephanolepis diaspros is the most abundant monacanthid. Currently, it has a relatively high occurrence in the landings of the trawl and purse seine fisheries, and a significant percentage of the benthos-demersal species in the small scale fishery. File fishes were discarded species till the 1990s (El-Ganainy et al., 2005), but it became an important commercial species in the middle of 1990s, and currently showed overfishing symptoms (El-Ganainy and Sabrah, 2008).

Biological information on the file fish $S$. diaspros is scarce, since there are some limited studies on the reproductive biology, behavior and stomach analysis of relative monacanthid species (Ishida and Tanaka, 1983; Barlow, 1987; Peristiwady and Geistdoerfer, 1991; Nakazono and Kawase, 1993; Kawase and Nakazono, 1996; Mancera-Rodrigues, 2000; Kawase, 2003 and Rim \& Mohamed, 2011).

This research is-so far-the first attempt to study the reproduction, the length at first sexual maturity and the feeding habits of S. diaspros in the Gulf of Suez and the Red Sea. This study aimed to throw light on the biological features including sex ratio, spawning activity and feeding habits of Stephanolepis diaspros that could help in the proper fishery management and is crucial for stock assessment of such fish. 


\section{MATERIAL AND METHODS}

Samples of the filefish Stephanolepis diaspros were collected from the commercial trawl catches landed at Attaqa fishing harbor during the period from November 2004 till March 2007. Total length in cm, total weight in gm, sex, stage of maturity and degree of fullness of the stomach for each sampled specimen were recorded. Sex and maturity stages were determined microscopically and weight of the gonads $(\mathrm{GW})$ was recorded to the nearest $0.01 \mathrm{~g}$. Stages of maturity were classified as follows: I immature; II developing; III mature; IV ripe; V running; and VI spent.

The sex ratio of the sampled population was analyzed monthly and according to the size intervals. The spawning season, condition and development of the gonads were determined following the monthly changes of the gonadosomatic index (GSI), calculating according to Anderson and Gutreuter (1983) as: $\quad$ GSI $=100 \mathrm{GW} / \mathrm{TW}$ Where GW is the gonad weight and TW is the total fish weight.

Size at maturity was determined as the length at which $50 \%$ of individuals were in maturity stages III and IV.

Stomach contents were analysed microscopically and identified to the lowest possible taxonomic level, depending on the type and digestion level of each prey item. For each identified prey, the percentage of occurrence $(\% \mathrm{O})$ and percentage composition \%C (Mohan and Sankaran, 1988) were calculated. The degree of stomach fullness was estimated by an arbitrary 0-4 point scale as follows: 4 for full, 3 for $3 / 4$ full, 2 for $1 / 2$ full, 1 for traces of food and 0 for empty stomachs. The fullness index was calculated as the number of empty stomachs divided by the total number of stomachs multiplied by 100 . Stomach contents were sorted into groups and analyzed for relative frequency (Hureau, 1969).

\section{RESULTS}

\section{Sex ratio}

The overall sex ratio of males to females was 1.00: 0.18 and the proportion of females was significantly much lower than males $\left(\chi^{2} 35.1 ; \mathrm{P}<0.001\right)$. The highest percentage of females was recorded in May (Fig 1). The variation in both the number and percentage of males and females in different length groups (Fig 2) show that males reach larger sizes. Females are represented in small sizes $(8.0-16.0 \mathrm{~cm})$, while males largely outnumber females up to the length interval of $16.0-26.0 \mathrm{~cm}$.

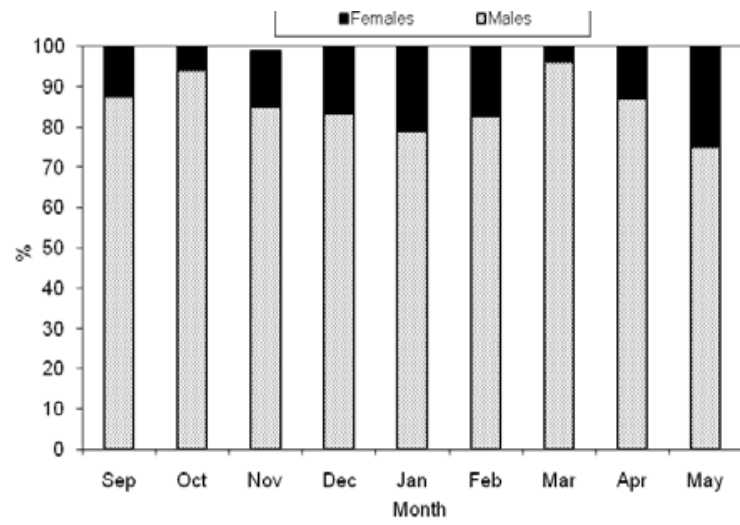

Fig (1) Monthly Variation in sex ratio of the filefish $S$ diasprosin the Ginlf of Snez.

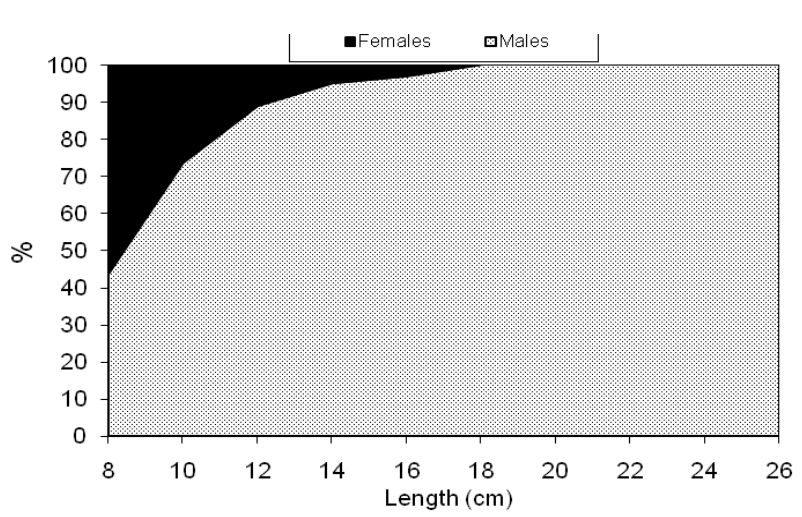

Fig (2) Variation in sex ratio according to length of $S$. diaspros in the Gulf of Sirez. 


\section{Spawning season}

The material used for this study covered ten months, (from September until June), as there was no available data during the closed season (summer). Analysis of the monthly variation in the GSI (Fig. 3) and different maturity stages (Figs. 4 \& 5) for males and females $S$. diaspros showed that the average values of gonad weight percentages increased substantially from March until June, while high values were recorded also during September. The maximum values were recorded in May; which indicates that $S$. diaspros spawns during summer, with an intensive spawning in May. Males and females in full ripe and running stages were found during May, June and September (Figs. 4 \& 5).

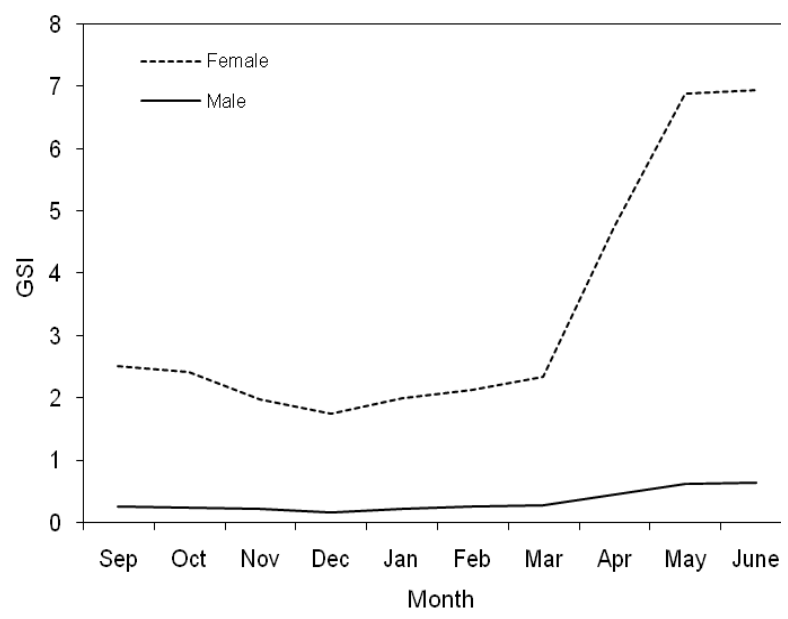

Fig (3) Monthly variations in gonadosomatic index (GSI) of S. diaspros from the Gulf of Suez.

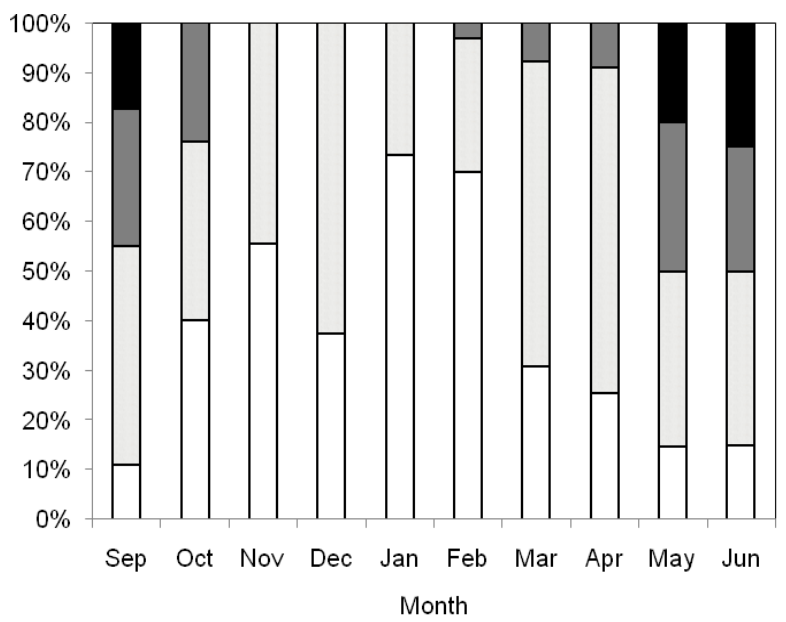

Fig ( 4 ) Monthly variations in different maturity stages of males $S$. diaspros from the Gulf of Suez.

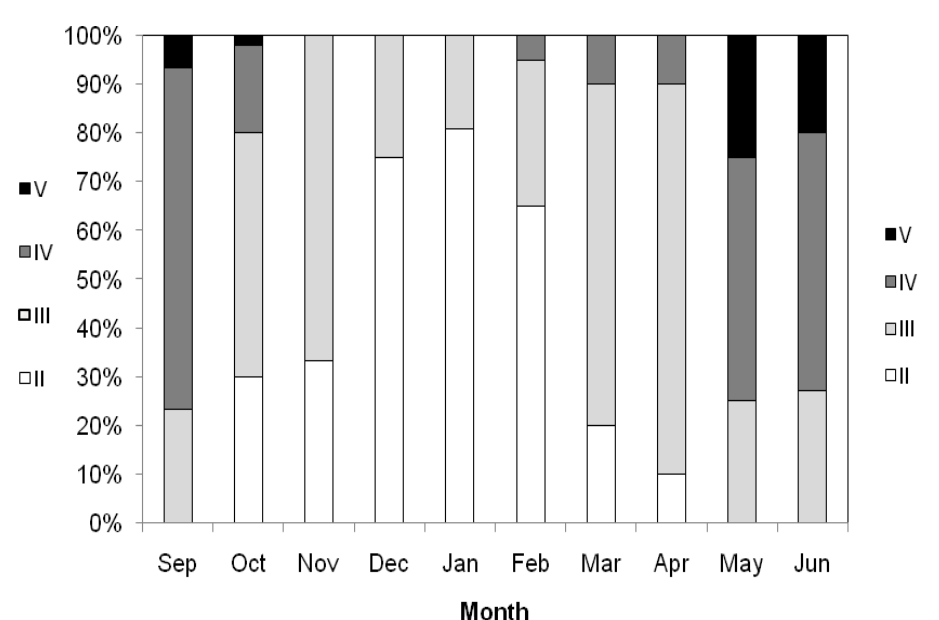

Fig (5) Monthly variations in different maturity stages of female S. diaspros from the Gulf of Suez.

\section{Size at first maturity}

Analysis of the percentage of mature and immature fish in each length class (Fig. 6) showed that the size at which $50 \%$ of fishes get mature is $9.5 \mathrm{~cm}$ for males and $8.5 \mathrm{~cm}$ for females. These indicate that all individuals get mature at the end of the first year of life. 


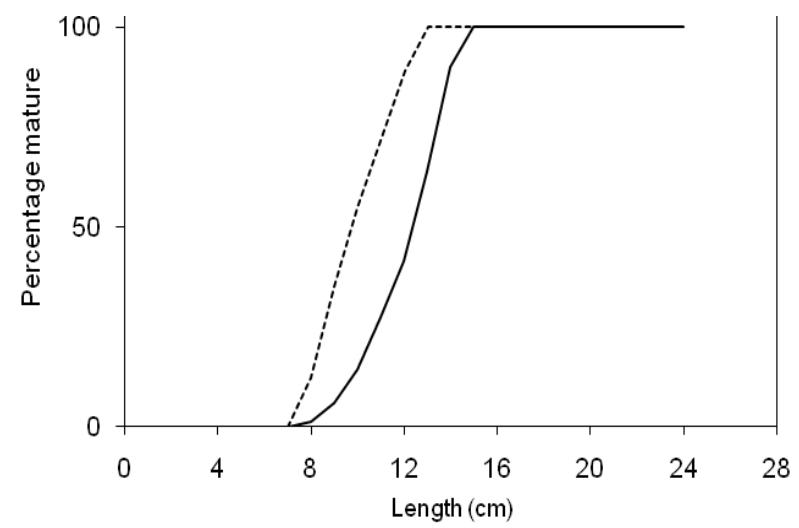

Fig ( 6 ) Length at sexual maturity $\left(\mathrm{L}_{50}\right)$ for females ........ \& males of $S$. diaspros from the Gulf of Suez.

\section{Stomach analysis}

A total of 288 stomachs were examined, in fish specimens ranged in length from $7.0 \mathrm{~cm}$. to $26.1 \mathrm{~cm}$. with an average of $14.59 \pm 3.61 \mathrm{~cm}$. From the total number of the examined specimens, 123 individuals had empty stomachs and 165 had full stomachs.

\section{Diet composition}

The diet of file fish consisted of a wide variety of items for males and females, as there is no significant difference $(p=0.084>0.05)$. Crustaceans and mollusks were dominating (Table 1). Crustaceans were clearly the most consumed item, scoring the highest values of percentage occurrence (45.91) and percentage composition (25.72). Mollusks were second, being mostly composed by shells of bivalves and gastropods.

Table 1: Percentage composition $(\% \mathrm{C})$ and percentage of frequency of occurrence $(\% \mathrm{O})$ of the different food items found in the stomachs of the file fish S. diaspros from the Gulf of Suez.

\begin{tabular}{|l|c|c|}
\hline Food items & $\% \mathrm{C}$ & $\% \mathrm{O}$ \\
\hline Crustacea & 25.72 & 45.91 \\
Crabs & 15.62 & 25.51 \\
Copepods & 4.6 & 8.16 \\
Isopods & 3.68 & 7.14 \\
Squilla sp. & 1.83 & 5.1 \\
Mollusca & 15.63 & 31.63 \\
Bivalves & 13.79 & 26.53 \\
Gastropods & 1.84 & 5.1 \\
Algae & 15.8 & 25.51 \\
Green algae & 20.22 & 23.47 \\
Echinoderms & & 21.45 \\
Sea Urchin & 8.46 & 8.16 \\
Fish remains & & \\
Scales and eggs & 6.44 & 2.04 \\
Porifera & & 5.88 \\
Sponges & 1.65 & 5.1 \\
Coelenterates & & \\
hydrozoans & 4.23 & \\
Protozoa & & \\
Foraminifera & & \\
Bryozoa & & \\
Bugula sp. & & \\
\hline
\end{tabular}


Algae especially the green ones were the third most important consumed group. Echinoderms were frequently consumed (23.5\%) and were the fourth most important prey group, particularly sea urchins. Fish remains, mainly scales and eggs, were also important in the diet of the file fish. Sponges, hydrozoans, foraminifera and Bryozoa (Bugula sp.) were also preyed by the file fish but at lower levels.

\section{Seasonal variation in the feeding intensity}

For the determination of the feeding intensity, all the examined individuals were classified whether their stomachs were empty or not (Fig. 7). Out of 288 fish were examined, 165 (57.29\%) had full stomachs, while 123 fish (42.71\%) had empty stomachs. The maximum feeding intensity was attained in spring, where most of the examined fishes $(91.5 \%)$ were found to be feeding. The minimum feeding intensity was observed during summer (June and September), where most of the examined stomachs $(71.9 \%)$ were found empty.

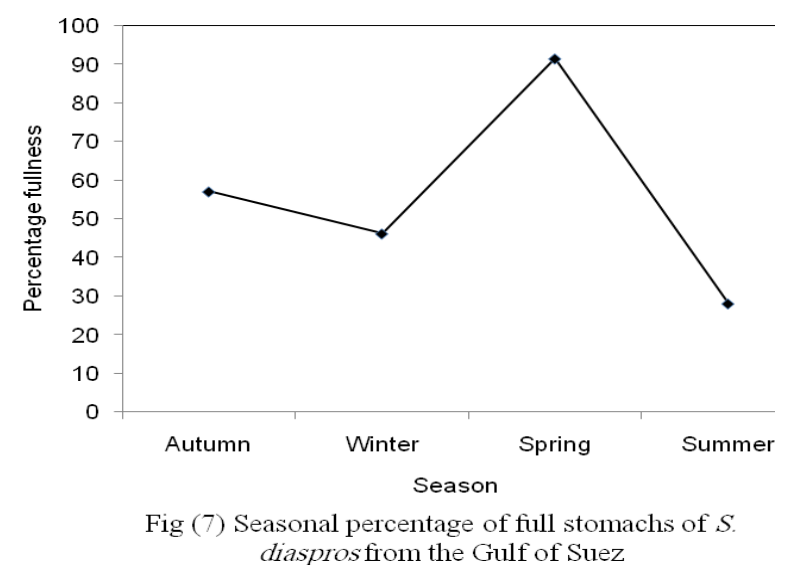

\section{Seasonal variations in food composition}

Seasonal variations in feeding habits were observed in terms of the percentage composition (Fig. 8). Crustaceans, mollusks and echinoderms were represented all over the year. The highest percentage of algae was recorded in summer, while the highest percentage of echinoderms was observed in winter. Fish remains were recorded by small ratio during spring only. There was no statical difference between seasons.

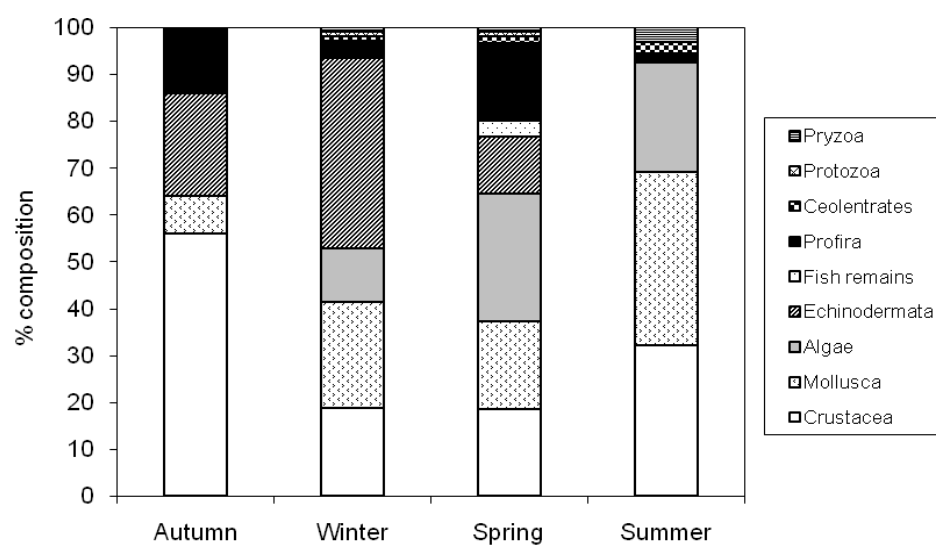

Fig (8) Seasonal vartiations in food composition of $S$. diaspros from the Gulf of Suez. 


\section{Food in relation to length}

In order to determine the effect of size on food habits of the file fish S. diaspros, the fishes from which stomachs have been examined, were grouped into 6 length groups $(3 \mathrm{~cm}$ intervals). The abundance of food items in each length group showed that crustaceans, mollusks, coelenterates and echinoderms (except small lengths $\leq 11.0$ $\mathrm{cm}$ ) are the major food items recorded in all length groups (Table 2). Algae were recorded by a relatively high ratio in fishes $\leq 17.0 \mathrm{~cm}$. Fish remains, foraminifers and bryozoans were dominating in small lengths $\leq 17.0 \mathrm{~cm}$ only. ANOVA test on different food items taken by different length groups revealed no significant difference between them.

Table 2: Percentage composition of different food items in different length groups of the file fish $S$. diaspros from the Gulf of Suez

\begin{tabular}{|c|c|c|c|c|c|c|}
\hline & \multicolumn{7}{|c|}{ Length intervals } \\
\hline Food item & $8.0-10.9$ & $11.0-13.9$ & $14.0-16.9$ & $17.0-19.9$ & $20.0-22.9$ & $23.0-25.9$ \\
\hline Crustacea & 22.45 & 25.5 & 26.04 & 29.73 & 42.31 & 35.71 \\
Mollusca & 13.03 & 10.95 & 14.5 & 14.76 & 1.28 & 22.32 \\
Algae & 20.22 & 15.41 & 12.81 & 2.16 & 7.69 & -- \\
Echinoderms & -- & 9.95 & 10.0 & 27.68 & 23.08 & 26.97 \\
Fish remains & 15.91 & 11.93 & 9.5 & -- & -- & -- \\
Porifera & 14.0 & 4.98 & 1.85 & -- & 7.78 & -- \\
Coelenterates & 9.0 & 14.05 & 18.3 & 25.67 & 17.86 & 15.0 \\
Protozoa & 2.22 & 3.35 & 4.2 & -- & -- & -- \\
Bryozoa & 3.17 & 3.88 & 2.8 & -- & -- & -- \\
\hline
\end{tabular}

\section{DISCUSSION}

Increasing of economical importance of file fish in recent years in the Gulf of Suez makes it important to have information on the different aspects of its natural history, in order to successfully manage its fishery.

Publications on the biology of the file fishes (Monacanthidae) are mostly limited, that may be due to its consideration as a by-catch and discarded species in many fisheries (Mancera-Rodriguez, and Castro-Hernández, 2004; El-Ganainy et al. 2005; El-Ganainy and Sabrah, 2008).

The monthly sex ratio of $S$. diaspros showed a predominance of males over females nearly during all the fishing season, and in sizes larger than $16 \mathrm{~cm}$. The variability of sex composition in fishes may be due to their selective natural and fishing mortalities between sexes; or by the segregation of the sexes through various periods of the year, including segregation resulting from sex difference in age and size at maturity (Smith, 1956). For the file fish, the very high percentage of males can be attributed to the disappearance of females after spawning (Nakazono and Kawase, 1993), and to the selective fishing mortality. Rim and Nejmeddine (2011) in the eastern Mediterranean Sea studied the reproductive biology S. diaspros in the Gulf of Gabes and reported that, the length frequency distribution indicated that males are taller than females and the sex-ratio of males to females was 1:0.87, which significantly deviated from the hypothetical distribution of 1:1. This can be attributed to that the size and the seasons have an effect on this sex-ratio. Mancera-Rodriguez (2000) attributed the larger growth rate in males of S. hispidus relative to females, to the length at maturity of females, being smaller than that of males. So, the decrease in percentage of females $S$. diaspros with the increase in length can be regarded to the difference in longevity and growth rate between the two sexes. 
The variations in maturity stages and gonado-somatic index were used for discrimination between the different conditions of the gonads in the different periods, in order to identify the spawning season. The results indicated that $S$. diaspros spawns during summer, with an intensive spawning in May and June, but the absence of data in the following months and the peak in September as well as the presence of high percentage of fish in full ripe and running maturity stages may lead to the assumption that the spawning season extends from May to September. Ishida and Tanaka (1983) reported that the spawning season of the file fish Rudarius ercodes extends from May to September in Japan. The estimated size at which 50\% of fishes get mature was 9.5 $\mathrm{cm}$ for males and $8.5 \mathrm{~cm}$ for females, these values is smaller than those (13.9 and 14.9 $\mathrm{cm}$ for females and males respectively) recorded by Mancera-Rodriguez (2000) for $S$. hispidus in Canary Islands. Tormosova (1983) suggested that food availability, and water temperature, besides the different environmental factors might affect the age, growth and the length at first sexual maturity of fishes.

Rim and Nejmeddine (2011) recorded that gonado-somatic Indices for $S$. diaspros were highest in July for both sexes and the first maturation $\left(\mathrm{L}_{50}\right)$ occurred at $7.8 \mathrm{~cm}$ for females and $9.7 \mathrm{~cm}$ for males. These may be relatively close to the current results. The estimated length at first maturity in this study is close to the length at first capture $\left(\mathrm{L}_{\mathrm{c}}=8.5 \mathrm{~cm}\right)$ estimated by El-Ganainy and Sabrah (2008). This implies that the fishery is depending on small individuals, and the stock dynamics of this species would be seriously affected. The high vulnerability of juvenile fish to capture by trawling would result in the reduction of the future yield of this species. Thus, the protection of juveniles is probably the key factor for the sustainability of such resource; through periodic spatial closure of the spawning and nursery areas. This may be achieved through the establishment of certain reserves in the Gulf of Suez to protect the spawning stock biomass, and then monitoring their effects as a management strategy (El-Ganainy and Sabrah, 2008).

The analysis of diet composition showed that the species is mainly omnivore, feeding on a wide variety of items due to the high productivity of the Gulf of Suez; a wide spectrum of food categories is available. Crustaceans, mollusks, echinoderms and algae were the dominant food items. Peristiwady and Geistdoerfer (1991) stated that the food of Monacanthus tomentosus in Indonesia consisted principally of gastropods, sea grasses, sponges, algae, amphipods and sedentary polychaetes. They also reported that pelecypods, opisthobranchs, isopods, copepods, ostracods, foraminiferans, bryozoans, ascidians, nematodes, mollusk eggs and fish eggs were found only in small percentages. The minimum feeding intensity was observed during summer (June and September), which coincides with the spawning period, i.e. the feeding activity of the file fish is affected by the reproductive cycle. Seasonal changes in the diet of $S$. diaspros reflect changes in the availability of food items. This was confirmed by the presence of high percentage of green algae in the stomachs of $S$. diaspros during spring, which is the blooming season for most of the green algae in the Gulf of Suez. The study of food items in relation to length group observed that small sizes $\leq 17.0 \mathrm{~cm}$ of file fish tend to eat more vigorously on all food items than larger fishes. This could be attributed to their preparation to the spawning maturation, as the fish attain their first sexual maturity at a small length.

\section{CONCLUSION}

For the proper management of file fishes in the Gulf of Suez, further multispecies studies based on stomach contents analysis should be conducted to 
investigate the interaction between species. Besides, a map for the spawning and nursery grounds of the filefishes in the Gulf of Suez should be prepared on the basis of sound biological research.

\section{REFERENCES}

Anderson, R.O. and Gutreuter, S. J. (1983). Length, weight, and associated structural indices. In: Nielsen, L.A., Johnson, D.L. (Eds.), Fisheries Techniques. American Fisheries Society, Bethesda, pp. 283-300.

Assadi, H. and Dehghani, R.P. (1997). Atlas of the Persian Gulf and the Sea of Oman fishes. Iranian Fisheries Research and Training Organization, Iran.

Barlow, G.W. (1987). Spawning, eggs and larvae of the longnose filefish Oxymonacanthus longirostris, a monogamous coralivore. Environ. Biol. Fish., 20 (3): 183-194.

El-Ganainy, A.A.; Yassien, M.H. and Awad, E.I. (2005). Bottom trawl discards in the Gulf of Suez, Red Sea. Egyptian Journal of Aquatic Research, 31:240 -255.

El-Ganainy, A. A. and Sabrah, M. M. (2008). Age, Growth, Mortality and Yield per Recruit of the Filefish Stephanolepis diaspros (Fraser-Brunner, 1940) (Pisces: Monacanthidae), in the Gulf of Suez, Egypt. J. Fish. Aqu. Sci., 3 (4): 252-260.

Golani, D.; Orsi-relini, L.; Massuti, E. and Quignard, J.-P. (2002). CIESM Atlas of Exotic Species in the Mediterranean. 256 p. Monaco: CIESM Publisher.

Hureau, J.C. (1969). Biologie compare' de quelques poisons antarctiques (Nothotheniidae). Bull. Inst. Oceanogr. (Monaco), 68: 1-44.

Hutchins, J.B. (1984). Monacanthidae. In: FAO Species Identification Sheets for Fishery Purposes. Western Indian Ocean (Fishing area 51), Vol. 3. Rome: FAO.

Ishida, Y. and Tanaka, S. (1983). Growth and maturation of the small filefish, Rudarius ercodes, in the Zostera bed in Odawa Bay. Bull. Jpn. Soc. Sci. Fish. 49: 547-553.

Kawase, H. (2003). Reproductive Behavior of Filefishes (Monacanthidae) at Tateyama Bay, Boso Peninsula, Japan. Journal of the Natural History Museum and Institute, Chiba.

Mancera-Rodr'iguez, N.J. (2000). Estudio de la Biolog'ia, Ecolog'ia y Pesquer'ia de Stephanolepis hispidus (Linnaeus, 1766) (Pisces: Monacanthidae) en aguas de Canarias. Ph.D. Thesis. Dep. of Biology, Univ. de Las Palmas de Gran Canaria, Las Palmas de Gran Canaria, Spain, 302 pp.

Mancera-Rodriguez, N.J. and Castro-Hernández, J. J. (2004). Age and growth of Stephanolepis hispidus (Linnaeus, 1766) (Pisces: Monacanthidae), in the Canary Islands area. Fish. Res., 66: 381-386.

Mohan, M.V. and Sankaran, T.M. (1988). Two new indices for stomach content analysis of fishes. J. Fish. Biol., 33: 289-292.

Nakazono, A. and Kawase, H. (1993). Spawning and biparental egg-care in a temperate filefish, Paramonacanthus japonicus (Monacanthidae). Environ. Biol. Fish., 37 (3): 245-256.

Peristiwady, T. and Geistdoerfer, P. (1991). Biological aspects of Monacanthus tomentosus (Monacanthidae) in the seagrass beds of Kotania Bay, West Seram, Moluccas, Indonesia. Mar. Biol., 109 (1): 135-139.

Persson, L.; Diehl, S.; Johansson, L.; Andersson, G. and Hamrin, S .F. (1991). Shifts in fish communities along the productivity gradient of temperate lakes-patterns and importance of size-structured interactions. J Fish. Biol., 38:281-293. 
Randall, J.F. (1995). Coastal Fishes of Oman. 439 pp. Honolulu: Univ. of Hawaii Press.

Rim, Z. K. and Nejmeddin, M. B, (2011). Reproductive biology of the lessepsian Reticulated leatherjacket Stephanolepis diaspros (Fraser - Brünner, 1940) in the Gulf of Gabes (Eastern Mediterranean Sea). Rev. Fish. Bio. Fish., 21 (3): 641-648.

Smith, S. (1956). Life history of lake herring of Green Bay, Lake Michigan. Fish. Bull. No. 109, Vol. 57, U. S. Fish. \& Wildl. Serv., 138pp.

Tormosova, I. D. (1983) Variation in the age at maturity of the North Sea haddock, lanogrammus aeglefinus (Gadidae). J. Ichthyol, 23:68-74

\section{ARABIC SUMMARY}

$$
\begin{aligned}
& \text { دراسات بيولوجية على اسماك الخنزيرة الخشنة ستيفانوليبس ديسبروس، فراسر - بروننر، 1940، } \\
& \text { (موناكانسيدى) من خليج السويس دئن } \\
& \text { عزة الجاينى و منال صبره } \\
& \text { المعهد القومى لعلوم البحار و المصايد، السويس، مصره }
\end{aligned}
$$

اصبحت اسماك الخنزيرة الخشنة ذات قيمة اقتصادية عالية و اقبال كبير من المستهلك منذ عام التهب 2003

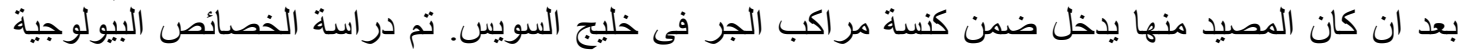

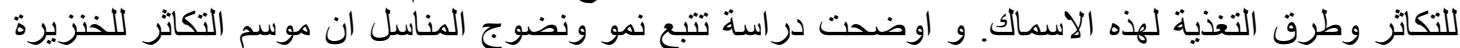

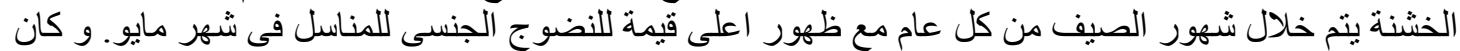

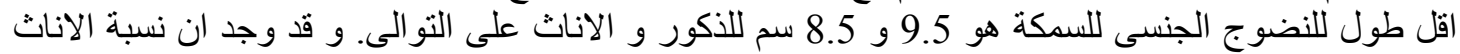

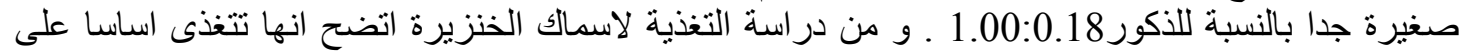

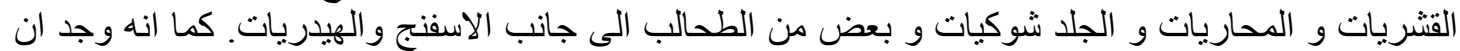

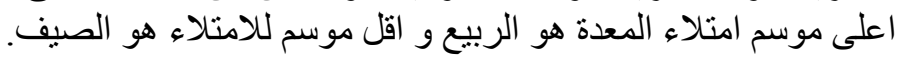

